\title{
POCHODZENIE LEGENDY O TRZECH KRÓLACH
}

Hołd, oddany nowonarodzonemu Zbawicielowi, jest charakterystycznym epizodem Ewangelii św. Mateusza (2,1-12). Opowiadanie to jednak nasuwa szereg problemów historycznych, z których nie wszystkie znalazły dotąd wy-

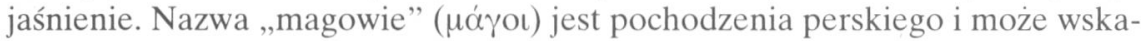
zywać zarówno na kapłanów irańskiego kultu ognia, jak i na astrologów babilońskich, którzy dobrze znali religijne tradycje dawnej Persji. W tym drugim przypadku jednak musieli oni przybyć z północy, podczas gdy Ewangelia (Mt 2,

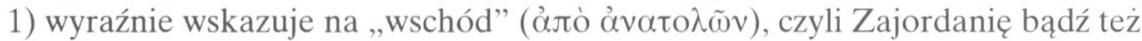
Arabię. Dary złożone przez magów są charakterystyczne dla południowej Arabii, skąd kupcy na wielbłądach przywozili je do Palestyny.

Opowiadanie ewangeliczne zdaje się też zakładać, że od narodzin Jezusa upłynęło już sporo czasu, około dwu lat (Mt 2,16). Chodzi więc o koniec rządów Heroda Wielkiego. Teksty paralelne z pisarzy klasycznych wskazują na historyczność narracji o magach; w zamyśle Ewangelisty jednak epizod ten ma głównie znaczenie teologiczne. Podkreśla on, że narodziny Jezusa w Betlejem są wypełnieniem proroctw biblijnych: Jezus będzie nie tylko Pasterzem Izraela (Mi 5,1), lecz także Królem narodów pogańskich (Iz 60, 5-12; Ps 72, 10-15).

Ks. Marek Starowieyski ${ }^{1}$ we wprowadzeniu do Ewangelii apokryficznych zwięźle przedstawił stan badań nad legendą Trzech Króli. Ostatnio A. de Jong ${ }^{2}$ przebadał szczegółowo tradycje o magach w literaturze klasycznej. Tutaj skupimy się tylko na kwestii proweniencji legendy, wyrosłej z przekazu ewangelicznego, i na imionach trzech mędrców, którzy stali się na pewnym etapie przekazu królami. Na koniec spróbujemy wyjaśnić, czemu wczesna tradycja lokalizuje magów w Arabii, skoro historia jednoznacznie wskazuje na Persję jako miejsce ich pochodzenia.

${ }^{1}$ Por. Apokryfy Nowego Testamentu, t. 1: Ewangelie apokryficzne, cz. 1, red. M. Starowieyski, Kraków 2003, 342-346 (Legenda Trzech Magów).

2 Por. Traditions of the Magi: Zoroastrianism in Greek and Latin Literature, Leiden 1997 (Religions in the Graeco-Roman World 133). 
Zacznijmy od sprecyzowania pojęcia „magowie” (gr. $\mu$ ójot), które zwykło się kojarzyć z kapłanami zoroastryzmu. Awesta jednak wymienia magów zaledwie raz (Yasna 65,7), i to nie w kontekście religijnym, lecz jako nazwę jednego z perskich rodów. Wynika stąd, że ich początków należy szukać nie w religii Zaratustry, lecz w instytucjach rodowych zachodniego Iranu. Staroperskie inskrypcje nie przypisują nigdy magom funkcji kapłańskich. W czasach Achemenidów magu jest wprawdzie członkiem rodu kapłańskiego, ale nie musi pełnić czynności sakralnych ${ }^{3}$. Dane Awesty nie sprzeciwiają się przy tym świadectwu pisarzy greckich, którzy mówią o udziale magów w obrzędach rytualnych ${ }^{4}$.

Od początku dynastii Achemenidów rysuje się opozycja pomiędzy zachodnioirańskimi magami a kapłanami zoroastryzmu, wywodzącego się ze wschodniego Iranu. Napięcie to będzie widoczne jeszcze w epoce Sasanidów (w. IIIVII po Chr.), kiedy to magowie (mowbed) stopniowo tracą pozycje w kapłaństwie hierarchicznym na rzecz niższej dotąd klasy herbedów ${ }^{5}$. Właśnie z początków tej epoki pochodzi Grota Skarbów, ważny dokument literacki chrześcijan syryjskich, żyjących na terenie dawnego królestwa Adiabeny. Od czasów Hadriana mieszkańcy Adiabeny byli poddanymi Partów, a następnie perskiej dynastii Sasanidów. Za rządów Szapura II (309-379) miejscowych chrześcijan dotknęły ciężkie prześladowania, owocując umocnieniem wiary ${ }^{6}$. W tym samym czasie rozwijał działalność pisarską Afrahat „mędrzec perski” z Nisibis ${ }^{7}$.

Grota Skarbów jest dziełem złożonym ${ }^{8}$; wzmianki o magach są wplecione w narrację wydarzeń, jakie miały miejsce po potopie, za dni Nemroda $(27,17-$ 22). W tym kontekście można przyjąć, że powstały one w środowisku asyrobabilońskim w Mezopotamii ${ }^{9}$. Właściwe opowiadanie o pokłonie trzech magów pojawia się w ostatniej części (rozdz. 45-54), będącej traktatem apologetycznym adresowanym do żydowskich uczonych w Piśmie. Oto najważniejszy fragment, dotyczący pokłonu magów; mieści się on w 45 rozdziale, na początku traktatu:

${ }^{3}$ Por. M. Boyce, A History of Zoroastrianism, vol. 2: Under the Achaemenians, Leiden 1982, 84-85.

${ }^{4}$ Por. Herodotus, Historiae I 101, 132, 140; VII 43; Xenophon, Memorabilia IV 5, 14; VII 5 , 57; VIII 1, 23.

${ }_{5}^{5}$ Por. M. Hunter, Religionen in der Umwelt des AT, Bd. 1: Babylonier, Syrer, Perser, Stuttgart 1996, 228-229.

${ }^{6}$ Szerzej pisze o tym N.W. Pigulewska, Kultura syryjska we wczesnym średniowieczu, tłum. Cz. Mazur, Warszawa 1989, 213-224.

${ }^{7}$ Por. M. Starowieyski, Stownik wczesnochrześcijańskiego piśmiennictwa Wschodu (= SWPW), Warszawa 1999, 6-7 (Afrahat Syryjczyk).

${ }^{8}$ Por. wyd. i tłum. A. Su-Min Ri, La caverne des trésors. Les deux recensions syriaques, CSCO 486-487 (Syr. 207-208), Louvain 1987; I. Ortiz de Urbina, Patrologia Syriaca, Romae 1965, 95-96 (Spelunca thesaurorum) ; Starowieyski, SWPW 123 (Jaskinia skarbów).

9 Aspekt antyjudaistyczny, powszechny od czasów Efrema, nie jest jeszcze obecny w utworze, por. A. Su-Min Ri, Commentaire de la «Caverne des trésors», Louvain 2000, 465. 
1. „Zobacz teraz, miłośniku nauki, bracie nasz Namosaja ${ }^{10}$, że w czterdziestym drugim roku rządów Augusta ${ }^{11}$ narodził się Chrystus w Betlejem judzkim, jak napisano w świętej Ewangelii (por. Łk 2,1).

2. Na dwa lata bowiem przed narodzeniem Chrystusa gwiazda ukazała się magom; ujrzeli ją na sklepieniu nieba, błyszczącą bardziej od wszystkich innych gwiazd.

3. Na niej była (widoczna) młoda kobieta brzemienna dzieckiem, a na jej głowie spoczywała korona ${ }^{12}$.

4. Królowie chaldejscy trzymają się zwyczaju, że całe ich postępowanie winno być zgodne ze znakami zodiaku.

5. Kiedy ujrzeli oni gwiazdę, zmieszali się i zlękli; ogarnęła ich bojaźń, a cała kraina Persji była poruszona,

6. zarówno królowie, jak i magowie, Persowie, Chaldejczycy i mędrcy perscy; ogarnęło ich zdumienie i wielki strach z tego powodu. I mówili:

7. «Czyżby to był Król Niebieski, który postanowił zstąpić do walki z Nemrodem»?

8. Chaldejczycy zaczęli studiować księgi swej mądrości i na podstawie tych ksiąg przekonali się o mocy prawdy.

9. Dzięki prawdzie bowiem chwalebne Słowo doprowadziło magów i Chaldejczyków do poznania przyszłych wydarzeń za sprawą biegu gwiazd, które nazywają oni zodiakiem.

10. Poznanie takie zostało dane tym, którzy podróżują po morzach, [aby] mogli wywnioskować z biegu gwiazd, jakie niebezpieczeństwo im grozi, i tak uniknąć gwałtownych wiatrów i rozbicia w burzy.

11. Tak więc magowie ci, czytając objawienie Nemroda, dowiedzieli się, że w Judei narodził się król, i został im objawiony cały przebieg planu mesjańskiego.

12. Zaraz też wyruszyli, zgodnie z tradycją otrzymaną od przodków; ze Wschodu udali się w góry Nebo, położone poza granicami Północy, i zabrali stamtąd złoto, mirrę i kadzidło.

13. Zrozum to, bracie mój Namosaja, że poznali oni całą posługę zawartą w planie naszego Zbawiciela, (wyrażając to) w zabranych darach:

14. złoto dla króla, mirra dla cierpienia, a kadzidło dla kapłana (por. Mt 2,11).

15. Wskazali oni, że będzie to król, lekarz i kapłan.

16. Gdy syn króla Szeby był jeszcze małym dzieckiem, ojciec zaprowadził go do domu nauczyciela (dosł. rabiego), aby poznał księgi hebrajskie lepiej niż wszyscy jego koledzy i rodacy.

17. On to powiedział swoim kolegom, że we wszystkich księgach genealogii jest napisane, iż król narodzi się w Betlejem (por. Mt 2, 5-6; Mi 5, 1).

${ }^{10}$ Przekład gruziński tłumaczy imię (,skrybowie”) i zmienia liczbę: „,bracia moi, pełni nauki”.

${ }^{11}$ Cezar August (29 prz. Chr. - 14 po Chr.)

12 Aluzja do Ap 12, 1n. 
18. I oto magowie przybyli ze Wschodu, przynosząc dary dla króla (jako) królowie i synowie królewscy:

19. Hormizdad z Makozdai - król Persji, nazywany „królem królów”, który mieszkał pod Ardugin; Azregad - król Saby, i Perozdad - król Szeby, która leży na Wschodzie" 13 .

Już powierzchowna lektura tego fragmentu wskazuje na jego rodzaj literacki. Jest to typowy midrasz judeochrześcijański, bazujący na tekście ewangelicznym (Mt 2, 1-12). Narracja biblijna została tu jednak znacznie poszerzona dzięki nawiązaniu do proroctw Starego Testamentu. Termin „magowie” pojawia się w Biblii po raz pierwszy w Księdze Daniela $(2,2.10)$ łącznie z „Chaldejczykami" jako określeniem astrologów. Wystarczyło to, aby i perskim magom nadać cechy badaczy zodiaku, których niezwykła gwiazda przywiodła do Betlejem judzkiego. Charakterystyczne, że w języku staroperskim określenie „ofiary” (magu) jest identyczne z nazwą „mag” (45, 18n); gra słów ułatwiła niewątpliwie rozwinięcie wątku o wizycie magów u żłóbka.

Z kolei wzmianka o trzech darach przyniesionych Zbawcy (Mt 2, 11; ,złoto, kadzidło i mirra") pozwoliła ustalić liczbę magów i nadać im imiona. Nie są to jeszcze imiona znane późniejszej tradycji (Kasper, Melchior, Baltazar), a wyrażające uniwersalizm objawienia. Tutaj imiona magów mają koloryt perski i nawiązują do imion władców z dynastii Sasanidów: Ardaszir, Hormizd i Peroz. Wszyscy oni zachowali się w pamięci chrześcijan jako władcy dobrzy, otwarci na dialog z wyznawcami Chrystusa. Ardaszir (225-240) był założycielem dynastii; on przypuszczalnie kryje się w legendzie pod imieniem „Azregada króla Saby”. Z kolei „Perozdad król Szeby” to może wyidealizowany obraz króla Peroza (459-484). Słabość Persji za jego rządów przyczyniła się do złagodzenia prześladowań chrześcijaństwa, jakie rozpoczęły się w IV wieku pod panowaniem Szapura II. Wreszcie „król królów” - Hormizdad z Makozdai, przypomina najbardziej historyczną postać Hormizda IV (579-590), o którym pogłoska mówiła, ze przyjął chrześcijaństwo ${ }^{14}$. Jeśli to on jest głównym bohaterem legendy o trzech królach, wówczas należałoby datować końcową redakcję Groty Skarbów na przełom VI i VII wieku.

Włączenie natomiast władców Saby i Szeby w historię Persji jest oczywiście legendarne. Jest ono śladem judeochrześcijańskiego midraszu, który odczytywał wydarzenia związane z narodzeniem Chrystusa w świetle proroctw Starego Testamentu (Ps 72, 10-15; Iz 60, 3-6) ${ }^{15}$. Ciekawa jest przy tym informacja, że król Szeby studiował w szkole rabinackiej i lepiej od swych kolegów znał święte „Księgi hebrajskie”. Wrócimy do tego tematu przy omawianiu następnego

13 Spelunca thesaurorum 45, CSCO 486 (Syr 207), 361-369, thum. własne.

14 Por. B. Składanek, Historia Persji, t. 1: Od czasów najdawniejszych do najazdu Arabów, Warszawa 2004, 253.

15 Koran $(27,22 ; 34,14.17)$ wymienia Sabejczyków, którzy chcieli korzystać z tolerancji religijnej, podając się za chrześcijan. 
(46.) rozdziału Groty Skarbów. Zawiera on wyjaśnienie faktu, że magowie byli jednocześnie królami:

1. „Wielkie było poruszenie w Judei, kiedy tam przybyli magowie. Obowiązywał tam jeszcze dekret cesarza Augusta, aby każdy pozostawał w swoim kraju i mieście ojców (por. Mt 2, 3; Łk 2,1).

2. Dlatego to Herod był bardzo poruszony i powiedział magom: «Idźcie i szukajcie go, ja bowiem jestem przyjacielem cesarza i cieszę się jego życzliwością» (por. J $19,12)$.

3. Chociaż swym strojem przypominali oni magów, w rzeczywistości byli królami. Poganie jednak mieli zwyczaj używać podczas składania ofiar i darów swym bogom podwójnego stroju: na strój królewski nakładali szaty magów.

4. Dlatego właśnie, przychodząc do Chrystusa z darami, mieli oni przygotowany podwójny strój.

5. Otóż, gdy wychodzili oni z Jeruzalem od Heroda, pokazała się im (ponownie) gwiazda, która towarzyszyła im w drodze, a oni bardzo się tym ucieszyli.

6. Gwiazda ta poprzedzała ich aż do chwili wejścia do groty. Wtedy to ujrzeli «Dziecię owinięte w pieluszki i złożone w żłobie» (Łk 2, 12. 16).

7. Kiedy wyruszali w drogę, mówili sobie, że po przybyciu na miejsce ujrzą wielkie dziwy, zgodnie $z$ ceremoniałem i zwyczajami panującymi w pałacach królewskich

8. podczas narodzin króla. Przypuszczali więc, że znajdą w ziemi Izraela królewskie pałace i złote kołyski, zdobne w zasłonki i dywany, księcia odzianego w purpurę, biegających żołnierzy i służbę królewską, dostojników ucztujących i znoszących podarki w wielkim porządku, smaczne dania i uczty przyjemne dla królów, srebrne i złote zastawy królewskie, sługi i służące, którzy z bojaźnią pełnią swą służbę.

9. Magowie spodziewali się ujrzeć to wszystko, lecz w rzeczywistości zobaczyli coś więcej. Gdy weszli do groty,

10. ujrzeli starego Józefa siedzącego w zadumie, oraz Maryję patrzącą z podziwem (por. Mt 2, 10).

11. Nie było nawet godnego łóżka ani stołu, ani żadnego sprzętu, używanego w ziemskim królestwie.

12. Kiedy ujrzeli całe to uniżenie i ubóstwo, nie ulegli zwątpieniu. Zbliżyli się z bojaźnią i oddali Mu pokłon ze czcią składając swe dary: złoto, mirrę i kadzidło (por. Mt 2,11).

13. Maryja i Józef byli bardzo zasmuceni, nie mogąc nic im ofiarować; oni jednak pożywili się $\mathrm{z}$ własnych zapasów.

14. Chrystus miał osiem dni, kiedy złożyli Mu swoje dary. Wypadało, aby Mu złożyli swe dary w dniu ósmym - (dniu) obrzezania.

15. W tej samej chwili, gdy Józef Go obrzezał, o zmierzchu, Maryja przyjęła dary.

16. Wprawdzie Józef obrzezał Go zgodnie z Prawem (por. Łk 2, 21-24),

17. dokonał jednak obrzezania, nie odejmując Mu niczego. 
18. Jak żelazo przecina promień słońca lub światła, nic mu nie ujmując, tak też Chrystus został obrzezany nie tracąc niczego.

19. Magowie pozostali u Niego w grocie przez trzy dni i widzieli zastępy niebieskie wstępujące i zstępujące na Chrystusa; słyszeli głosy aniołów, którzy wielbili Go wołając:

20. «Święty, święty, święty Pan, Bóg wszechmogący, gdyż Jego chwała wypełnia niebo i ziemię" (Łk 2, 13; Iz 6, 3).

21. Byli oni zdjęci wielką bojaźnią; wierzyli jednak, że jest to Król, który zstąpił z nieba i stał się Człowiekiem.

22. Perozdad zaś odpowiedział: «Teraz wiem, że prawdziwe jest proroctwo Izajasza; gdy bowiem byłem w szkole hebrajskiej, czytałem Izajasza i znalazłem tam: 'Albowiem Dziecię nam się narodziło, Syn został nam dany, na Jego barkach spoczęła władza. Nazwano Go imieniem Przedziwny, Doradca, Bóg i Mocarz wieczny' (Iz 9, 5; por. 45, 19)».

23. A w innym miejscu jest napisane: «Oto Dziewica pocznie porodzi Syna, a będzie On nazwany imieniem Emanuel» (Iz 7, 14; Mt 1, 23). Czy wiecie, co to jest, czy nie? «Emanuel znaczy bowiem 'Bóg z nami’». On jest prawdziwym Emanuelem,

24. ponieważ, gdyby dla nas tylko stał się człowiekiem, to aniołowie nie zstąpiliby z nieba na Niego! On jest prawdziwie Panem aniołów i ludzi.

25. Uwierzyli oni wszyscy i zawołali: «Król ten jest prawdziwie Bogiem. W naszym kraju bowiem aniołowie nie zstąpili na nas, (chociaż) zrodziliśmy się z królów i synów królewskich, z mocarzy i synów mocarzy».

26. Oddali więc pokłon jako przed Panem i Królem. A gdy poczynili wszystkie zapasy, ruszyli w swą drogę, ku pustyni" (por. Mt 2, 12b) ${ }^{16}$.

Pomijając wstawkę o tajemnicy obrzezania (ww. 15-18), cały rozdział 46 rozwija ewangeliczną scenę pokłonu magów. Charakterystyczne jest przy tym utożsamienie magów z królami, pod wpływem cytowanych już proroctw (Iz 60 i Ps 72). Motyw literacki „trzech króli” mógł być zapożyczony z Testamentu Joba $(30,2)^{17}$. Na wybór ,trzech” króli niewątpliwie wpłynęło skojarzenie sceny ewangelicznej z opowiadaniem o trzech młodzieńcach, wyznających swą wiarę w piecu ognistym (Dn 3). Ponieważ opowiadanie to sąsiaduje ze wzmianką o magach (Dn 2), autor midraszu mógł bez trudności ustalić liczbę magów przybyłych pokłonić się Chrystusowi. Pierwszym śladem znajomości tej tradycji w Kościele zachodnim jest wzmianka u Tertuliana ${ }^{18}$;

16 Spelunca thesaurorum 46, CSCO 486 (Syr 207), 373-381, thum. własne.

17 Apokryf pochodzący ze środowiska aleksandryjskiego opiera się tu na Septuagincie, która w Hi 2, 11 nazywa przyjaciół Hioba „królami”, por. The O. T. Pseudepigrapha, ed. J.H. Charlesworth, vol. 1, New York 1985, 852.

18 Por. Adversus Marcionem III 13, 8, CCL 1, 525, tłum. S. Ryznar, PSP 58, 120: „Bo magów i królów miał pewnie cały Wschód, a Damaszek do Arabii był dawniej zaliczany, zanim ta przemianowana została na Syrofenicję w odróżnieniu od Syrii; od niej wtedy otrzymał Chrystus bo- 
Cezary z Arles ${ }^{19}$ uważa ją już za oczywistą. Elementy irańskie, zwłaszcza wzmianka o „podwójnym stroju” magów $(46,3$ n), zgodne są z podwójną funkcją pełnioną przez królów irańskich epoki Sasanidów, podobnie jak u Partów ${ }^{20}$.

W zakończeniu rozdziału 46 Groty Skarbów pojawia się wyznanie Perozdada, króla Szeby. To właśnie on studiował niegdyś „,w szkole hebrajskiej” i tam nauczył się midraszu. Łącząc umiejętnie proroctwa Izajasza z kontemplacją tajemnicy Dziecięcia, dostrzegł w Nim „Pana aniołów i ludzi”. Świadectwo uczonego w Piśmie doprowadziło pozostałych królów do wyznania: „Król ten jest prawdziwie Bogiem" "21. Postawa Trzech Króli różni się diametralnie od postawy króla Heroda; mówi o tym ostatnia wzmianka o magach w tekście Groty Skarbów:

„Herod dopytywał się wtedy o magów, a skoro dowiedział się, że wrócili do swego kraju, rozgniewał się bardzo i zaraz kazał pozabijać wszystkie dzieci i niemowlęta w Betlejem i w całej okolicy"22.

Tekst syryjski jest tu w pełni zgodny z danymi Ewangelii, która stwierdza, że

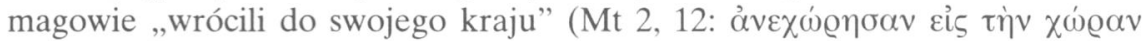
$\alpha$ $\left.\jmath_{\tilde{\omega}} v\right)$. To ostatnie stwierdzenie pozwala przypuszczać, że mieli oni wspólną ojczyznę. Trudno jednak dokładnie określić jej położenie na podstawie ogólnej wzmianki o „magach ze wschodu” (Mt 2,1). Najstarsza tradycja patrystyczna (Justyn i Tertulian) ${ }^{23}$ mówi o Arabii, chociaż w Arabii nie było magów. Od początku III wieku jednak coraz częściej wymienia się Persję jako ich ojczyznę. Łatwo pogodzić obydwie tradycje, gdyż Tertulian, zmarły ok. roku 220, nie mógł jeszcze znać nazwy Persja, która rozpowszechniła się z nastaniem dynastii Sasanidów (225).

Pierwszym świadectwem perskiej lokalizacji magów jest wzmianka u Klemensa Aleksandryjskiego. Mówi on, że:

„filozofia, stanowiąc owocodajne dobro, doszła do rozkwitu w dawnych czasach najpierw u barbarzyńców, a później u Hellenów. Zaopiekowali się nią po kolei kapłani egipscy i Chaldejczycy w Asyrii, wśród Baktrów Salmanowie, wśród Celtów filozofowie, u Persów magowie. Ci ostatni nawet dzięki swej sztuce profetycz-

gactwa w symbolicznym złocie i pachnidłach, a za łupy z Samarii uznano tych samych Magów, którzy skoro Go poznali i uczcili darami i na kolanach złożyli Mu pokłon jako Bogu i Królowi, stali się łupem z Samarii, to jest krainy bałwochwalstwa, bo mianowicie uwierzyli w Chrystusa".

${ }^{19}$ Por. Homilia 139, 2, PL 39, 2018; zob. Ewangelie apokryficzne, cz. 1, red. Starowieyski, s. 343.

${ }^{20}$ Por. Su-Min Ri, Commentaire, s. 465.

21 Por. wyznanie Tomasza w J 20, 28.

22 Spelunca thesaurorum 47, 12-13, CSCO 486 (Syr 207), 388.

${ }^{23}$ Por. Justinus, Dialogus cum Judaeo Tryphone 77, 4; 78, 1; 88, 1; Tertullianus, Adversus Judaeos 9; Adversus Marcionem III 13, 8. 
nej przewidzieli przyjście na świat Zbawiciela i pod przewodnictwem gwiazdy przybyli do ziemi judejskiej" 24 .

Lokalizacja chaldejska pojawia się dość późno, w początku V wieku, zapewne w oparciu o to samo świadectwo Klemensa z Aleksandrii ${ }^{25}$.

Imiona Trzech Króli są poświadczone dopiero w VI wieku. Znamy już ich wersję perską, przechowaną w cytowanym tekście Groty Skarbów. Inne wersje językowe można znaleźć w nieocenionym zbiorze Ewangelii apokryficznych, wydanym przez ks. M. Starowieyskiego. I tak ormiańska Ewangelia Dzieciństwa, thumaczona z syryjskiego, przechowała trzy imiona królów, którzy tym razem przybywają już z różnych krain:

„Najpierw przyszedł Gaspar, król Indii [...]. Następnie Baltazar król Arabów [...]. Z kolei Melkon, król Persów"26.

Podobnie brzmią ich imiona na mozaice bazyliki San Apollinare Nuovo w Rawennie (VI wiek): Balthazar, Melchior, Casper. W łacińskim przekładzie kroniki pochodzącej z Aleksandrii (również VI wiek) imiona są nieco zniekształcone, ale wskazują na wspólny wzorzec: Bethisarea, Melchior, Gathaspa ${ }^{27}$.

Dwa spośród tych imion wywodzą się jeszcze z midraszowej lektury Księgi Daniela. Łącznikiem pomiędzy 2 i 3 rozdziałem tej księgi jest mianowicie zdanie, które przypomina pokłon Trzech Króli: „Nabuchodonozor upadł na twarz i oddał pokłon Danielowi, nakazując złożyć mu dary i wonne kadzidła" (Dn 2, 46). Daniel jest tu figurą Zbawiciela, a jego drugie imię, nadane mu przez króla, brzmi Belteszassar. W wersji łacińskiej nie różni się ono od imienia króla Baltazara (por. Dn 4, 5 i 5, 1). Z kolei imię Kasper wywodzi się z perskiego słowa gi(n)zbar, „strażnik skarbca”, i w rzeczywistości jest jednym z tytułów możnowładców chaldejskich, którzy mieli złożyć pokłon przed posągiem króla (Dn 3, 2n $)^{28}$. Wreszcie imię Melchior łatwo odczytać jako hebrajskie imię teoforyczne: „Król światła”. W aramejskim tekście Daniela pojawia się „król chaldejski Baltazar” $(5,30)$, który dalej $(7,1)$ nazwany jest „królem babilońskim”; nadto Ezd 4, 24 mówi o „Dariuszu, królu perskim (melek-paras)". Ta ostatnia forma trafiła do ormiańskiej Ewangelii Dzieciństwa, a także do tradycji etiopskiej ${ }^{29}$.

24 Stromata I 15, 71, 3-2 GCS 52, 45, thum. J. Niemirska-Pliszczyńska: Klemens Aleksandryjski, Kobierce, I, Warszawa 1994, 52-53; por. Origenes, Contra Celsum I 24.

25 Por. Maximus Tauriensis, Homiliae 18-28 (de Epiphania).

${ }^{26}$ Ewangelia Dzieciństwa ormiańska 11, 17, tłum. E. Nowak, w: Ewangelie apokryficzne, cz. 1, Kraków 2003, 480.

27 Por. Excerpta latina barbari; zob. Ewangelie apokryficzne, cz. 1, red. Starowieyski, s. 344.

${ }^{28}$ W Dn 3, 2-3 pisownia jest nieco inna, ale Ezd 7, 21 zachował formę pierwotną; por. tez nazwisko Ginzberg.

${ }^{29}$ Por. Tanisuran, Malik, Siseb; zob. Ewangelie apokryficzne, cz. 1, red. Starowieyski, s. 344. 
Niniejszy przyczynek umieszczam w zbiorze prac poświęconych wielkiemu miłośnikowi starożytnej literatury chrześcijańskiej, ks. prof. Markowi Starowieyskiemu. Chciałbym w ten sposób wyrazić Mu swoje podziękowanie za inspirację do współpracy między biblistami a patrologami, zwłaszcza w dziedzinie badań nad apokryfami.

PROVENIENZA DELLA LEGENDA SUI TRE RE

(Riassunto)

Il tema di questo saggio tocca ai radici stessi della narrazione evangelica ben nota in tutto mondo cristiano (Mt 2,1-12). L'autore mostra il strato primitivo della legenda nella tradizione ecclesiastica siriaca. Basando sul testo di Caverna dei Tesori (tradotto qui per la prima volta in lingua polacca) si vede, che tutti i tre nomi dei Re erano di provenienza persiana e probabilmente alludevano ai nomi storici dei imperatori dalla dinastia sassanida, favorevoli ai cristiani. La tradizione primitiva (Giustino, Tertulliano) localizzava dei maghi in Arabia, ma il nome dei Persi si legge gia presso Clemente Alessandrino, cioe dopo l'iniziazione della dinastia dei Sassanidi (ca. 225) e dopo la rinnovazione dell'impero persiano. 